\title{
A laboratory study using maple leaves as a biosorbent for lead removal from aqueous solutions
}

[Short title: Maple leaves as a novel biosorbent]

Md Anwar Hossain, Huu Hao Ngo, Wenshan Guo, Jian Zhang and Shuang Liang

Md Anwar Hossain

Huu Hao Ngo (corresponding author)

\section{Wenshan Guo}

Centre for Technology in Water and Wastewater, School of Civil and Environmental

Engineering, University of Technology Sydney, Broadway, NSW 2007, Australia

E-mail: h.ngo@uts.edu.au

\section{Jian Zhang}

\section{Shuang Liang}

Shandong Provincial Key Laboratory of Water Pollution Control and Resource Reuse, School of Environmental Science and Engineering, Shandong University, Jinan 250100, China

\section{ABSTRACT}

This study tested the ability of maple leaf powder (MLP) to reduce the level of $\mathrm{Pb}$ (II) ions in aqueous solutions. As a biosorbent, MLP has a larger specific surface area $\left(10.94 \mathrm{~m}^{2} / \mathrm{g}\right)$ and contains $\mathrm{Pb}$ (II) binding functional groups. The highest $\mathrm{Pb}$ (II) removals were achieved at $\mathrm{pH}$ of 6.2, particle size of less than $75 \mu \mathrm{m}$, dose of $0.5 \mathrm{~g}$, initial concentration of $10 \mathrm{mg} / \mathrm{l}$ and equilibrium time of $>15$ minutes. Thermodynamic results indicated that the $\mathrm{Pb}$ (II) adsorption process was spontaneous and exothermic. MLP biosorbent could be reused for five cycles after successfully recovery by $0.1 \mathrm{~N} \mathrm{H}_{2} \mathrm{SO}_{4}$. Both adsorption and desorption data fit well with Langmuir and Sips isotherm models $\left(R^{2} \approx 0.961-1.00\right)$. The $\mathrm{Pb}(\mathrm{II})$ adsorption and desorption capacities $\left(q_{m}\right)$ of MLP were up to $50.27 \mathrm{mg} / \mathrm{g}$ and $40.06 \mathrm{mg} / \mathrm{g}$, respectively, for a $1 \mathrm{~g}$ dose at room temperature. Kinetics processes were rate controlling step and showed good fitness with the pseudo-second order and intraparticle diffusion models. Results suggest that multiple mechanisms (chelating bond, physisorption and chemisorption) are involved to adsorb the $\mathrm{Pb}$ (II) ions on to MLP. Higher $\mathrm{Pb}$ (II) removal revealed the practical applicability of MLP in water and wastewater treatment systems.

Key words | adsorption, desorption, isotherm, maple leaves, regeneration

\section{INTRODUCTION}

Lead smelting, mining, ceramics and glass production, leaded gasoline and batteries, and the printing, tanning, plating and finishing industries effluents are sources of $\mathrm{Pb}$ (II) contamination 
of water bodies and other natural environments. $\mathrm{Pb}(\mathrm{II})$ adversely affects terrestrial and aquatic biota and threatens human health (El-Ashtoukhy et al. 2008; Santorufo et al. 2012). Exceeding the permissible limit of $\mathrm{Pb}(\mathrm{II})$ in drinking water $(0.05 \mathrm{mg} / \mathrm{l})$ may cause adverse reaction with 'mercapto group' and 'phosphate ion' of enzymes, ligands and biomolecules, inhibit the biosynthesis of haeme units, affect the membrane permeability of kidney, liver and brain cells, and ultimately results in either reduced functioning or complete breakdown of these organs (Okoye et al. 2010). It is essential to eliminate $\mathrm{Pb}(\mathrm{II})$ from water and wastewater prior to discharge into natural environments.

Several conventional methods (e.g., chemical precipitation, ions exchange, ultrafiltration, etc.) are employed to remove $\mathrm{Pb}$ (II) from water and wastewater, but they do so incompletely, need large quantities of reagents and energy, and generate toxic sludge that requires expensive disposal (Amuda \& Alade 2006). Biosorption is an innovative and developing technology using living or dead bio-materials to reduce toxic heavy metals in aqueous solutions. The key advantages of biosorption technology are its effectiveness in reducing the concentration of heavy metal ions to very low levels and its use of inexpensive bio-materials (Volesky \& Holan 1995). A wide variety of agricultural waste materials, such as modified palm oil empty fruit branch (Ibrahim et al. 2010), meranti sawdust (Rafatullah et al. 2009), olive tree pruning waste (Blázquez et al. 2011), Nordmann fir (Kay et al. 2009), groundnut hull (Qaiser et al. 2009), green alga (Ulva lactuca) biomass (Sarı \& Tuzen 2008), cotton waste biomass (Riaz et al. 2009), modified peanut sawdust (Li et al. 2007), grape stalks (Martínez et al. 2006), activated carbon prepared from apricot stone (Kobya et al. 2005) and coconut shell (Sekar et al. 2004), are already used as low-cost biosorbents for $\mathrm{Pb}$ (II) removal from water. In addition, the lignocellulosic solid wastes generated in the agricultural, plantation and forestry sectors have been proposed as an alternative potential biosorbent for the removal and recovery of heavy metal ions water and wastewater (Demirbas 2008). The maple tree is commercially, environmentally and aesthetically important in many temperate and polar regions of the world (Rahman \& Islam 2009; Witek-Krowiak et al. 2010).

Maple wood is in great demand for flooring, furniture, interior woodwork, veneer and small woodenware due to its hardness, toughness and other properties, and maple trees are frequently grown as roadside decoration (Witek-Krowiak et al. 2010). Consequently, a huge amount of maple leaves are produced every year, creating a waste management problem in many regions. To date, no commercially viable uses of maple leaves have been reported.

In this article, steps were taken to describe an evaluation of the capacity of maple leaves to adsorb $\mathrm{Pb}$ (II) ions from aqueous solutions. It was characterised by FTIR, BET, SEM and X- 
ray mapping. It also studied the effects of contact time, the $p H$ of the solution, the initial concentration of $\mathrm{Pb}$ (II) ions and dosage of the adsorbents, particle sizes and temperature on removal of $\mathrm{Pb}(\mathrm{II})$ ions by MLP. This research also investigated the adsorption and desorption isotherms of $\mathrm{Pb}(\mathrm{II})$ and the probable mechanism of $\mathrm{Pb}$ (II) biosorption, and determined the kinetics characteristics of $\mathrm{Pb}(\mathrm{II})$ adsorption and desorption on the surface of maple leaves.

\section{MATERIALS AND METHODS}

\section{Materials}

One kilogram of maple leaves were collected from a plantation in Oswald Reverse, Oswald Street, New South Wales, Australia between May and June 2012. The leaves were washed to remove impurities such as sand and twigs, and the washed leaves were chopped and then dried at $105{ }^{\circ} \mathrm{C}$ for 24 hours in an oven. The dried leaves were then removed and ground in a coffee grinder. The resulting powder was sieved and graded into $<75 \mu \mathrm{m}, 75 \mu \mathrm{m}, 150 \mu \mathrm{m}$ and $300 \mu \mathrm{m}$ sizes. A stock solution of lead nitrate $\left(\mathrm{Pb}\left(\mathrm{NO}_{3}\right)_{2}\right)$ was prepared by dissolving an accurately weighed amount $(1.598 \mathrm{~g})$ of the salt in 1 litre of Milli-Q water to prepare 1 litre of $1000 \mathrm{mg} / \mathrm{l}$ solution. Experimental solutions were prepared by diluting the stock solution with distilled water.

\section{Methods}

BET specific surface area

The BET surface area of the MLP was determined from $\mathrm{N}_{2}$ adsorption isotherm by Nano Porosity System (Micrometrics ASAP 2020, Mirae SI, Korea).

Fourier transforms infrared (FTIR) spectroscopy

The FTIR spectra of the MLP were recorded on a FTIR spectrometer (Shimadzu FTIR 8400S, Kyoto, Japan) to elucidate the functional groups present.

\section{Scanning electron microscope}

SEM was used to examine the surface morphology of the MLP and obtained images on JEOL (JSM-35CF, UK). Elemental mapping was conducted using an energy-dispersive X-ray spectrometer attached to the SEM.

Effect of particle sizes

Experiments were conducted in Erlenmeyer flask containing $100 \mathrm{ml}$ water with 1 to $500 \mathrm{mg} / \mathrm{l}$ of $\mathrm{Pb}$ (II) concentration; $0.5 \mathrm{~g}$ of MLP of each particle size were added to each experiment. The Erlenmeyer flasks were shaken at $120 \mathrm{rpm}$ and at room temperature for 2 hours. The water samples were filtered with Whatman ${ }^{\mathrm{TM}}$ filters $(\mathrm{GF} / \mathrm{C}-47 \mathrm{~mm}$ circle; GE Healthcare, Buckinghamshire, UK) and the filtrates were analysed by atomic absorption spectrometer (AAS) (ContraÒAA 300, Analytikjena, Germany). 


\section{Effect of biosorbent doses}

Batch adsorption tests were conducted with doses of MLP from $0.01 \mathrm{~g}$ to $3.0 \mathrm{~g}$ per $100 \mathrm{ml}$ solution of $1-15 \mathrm{mg} / \mathrm{l}$ of $\mathrm{Pb}$ (II) ion at $p H 6.0$, for a contact time of $120 \mathrm{~min}$ at room temperature. The samples were shaken at $120 \mathrm{rpm}$ and filtered with Whatman filters, then the filtrates were analysed by AAS.

\section{Effect of solution pH on biosorption}

The effect of $p H$ on the adsorption capacity of MLP was investigated using a $100 \mathrm{ml}$ solution of $10 \mathrm{mg} / \mathrm{l}$ of $\mathrm{Pb}(\mathrm{II})$ ion and a $\mathrm{pH}$ range of 2.0 to 7.0 at room temperature. Experiments could not be performed at higher $p H$ value due to hydrolysis and precipitation of $\mathrm{Pb}(\mathrm{II})$ ions. Erlenmeyer flasks were shaken for $120 \mathrm{~min}$ to ensure that equilibrium was reached. The mixtures were then filtered using Whatman filters and the filtrates were measured by AAS.

\section{Desorption experiments}

Desorption experiments were performed to explore the possibility of repeated use of the biosorbents. After biosorption experiments, the $\mathrm{Pb}(\mathrm{II})$-loaded biosorbent was washed and transferred to $100 \mathrm{ml}$ of eight types of eluent: tap water, milli-Q water, distilled water, $0.1 \mathrm{~N}$ $\mathrm{H}_{2} \mathrm{SO}_{4}, 0.1 \mathrm{~N} \mathrm{HCl}, 0.1 \mathrm{~N} \mathrm{HNO}_{3}, 0.1 \mathrm{~N} \mathrm{NaOH}$ and $0.1 \mathrm{~N} \mathrm{CH}_{3} \mathrm{COOH}$. The Erlenmeyer flasks with samples were agitated at $120 \mathrm{rpm}$ and at room temperature for 3 hours. Samples were filtered with Whatman filters and $\mathrm{Pb}(\mathrm{II})$ ions desorbed in the filtrate were determined. The eluted adsorbent was washed repeatedly with Milli-Q water to remove any residual desorbing solution and placed into metal-containing water for the next adsorption cycle. Adsorption and desorption cycles were run six times with the best eluent under the same conditions.

Kinetics and effect of initial Pb(II) concentration

Kinetic experiments were carried out by agitating 1,000 $\mathrm{ml}$ of $\mathrm{Pb}(\mathrm{II})$ solution of concentration ranging from 10 to $200 \mathrm{mg} / \mathrm{l}$ with $5 \mathrm{~g}$ of MLP in a beaker at room temperature and an optimum $p H$ of 6.0 at a constant speed of $120 \mathrm{rpm}$ for $180 \mathrm{~min}$. Samples $(5.0 \mathrm{ml})$ were pumped by syringe at different time intervals, filtered by Millipore filter and the concentration of $\mathrm{Pb}$ (II) analysed by AAS. The quantity of $\mathrm{Pb}$ (II) ions retained in the biosorbent phase $\left(q_{t}, \mathrm{mg} / \mathrm{g}\right)$ was calculated by the following expression:

$q_{t}=\frac{\left(C_{o}-C_{t}\right) \cdot V}{m}$

where $C_{0}$ is the initial concentration, $C_{t}$ is the concentration of the $\mathrm{Pb}(\mathrm{II})$ at time $\mathrm{t}(\mathrm{mg} / \mathrm{l}), V$ is the water volume (l) and ' $m$ ' is the mass of the biosorbent (g).

The filtrate powder was washed with Milli-Q water to remove any residual desorbed $\mathrm{Pb}(\mathrm{II})$ and used for desorption kinetics with best eluent. The kinetics data for adsorption and 
desorption were fitted to the pseudo-first-order, pseudo-second-order and intraparticle diffusion models. The parameters of the models were optimised by non-linear analyses. The relationship between experimental $q_{t}$ and model-predicted $q_{t}$ was determined by the coefficient of determination $\left(R^{2}\right)$ (Hossain et al. 2012). The degree of fitness of kinetics models was also judged by two non-linear errors: the normalised standard deviation $(N S D)$ and average relative error (ARE) (Hossain et al. 2012).

\section{Equilibrium studies}

A volume of $100 \mathrm{ml}$ of $\mathrm{Pb}(\mathrm{II})$ solution with a range of 1 to $500 \mathrm{mg} / \mathrm{l}$ was placed in $150 \mathrm{ml}$ of Erlenmeyer flasks (16 for each dose) at $p H$ 6-6.5. Accurately weighed amounts $(0.05,0.5$ and $1 \mathrm{~g}$ ) of MLP were added to separate flasks. The Erlenmeyer flasks were shaken at $120 \mathrm{rpm}$ and at room temperature for $120 \mathrm{~min}$, then the MLP were separated by Whatman filters. The filtrated MLP was washed with Milli-Q water to remove any residual desorbing $\mathrm{Pb}(\mathrm{II})$ and used for desorption equilibrium in $100 \mathrm{ml}$ of best eluent. The filtrate was analysed for the remaining $\mathrm{Pb}(\mathrm{II})$ concentration by $\mathrm{AAS}$. Adsorption and desorption capacities $\left(q_{e}\right)$ were calculated as:

$q_{t}=\frac{\left(C_{o}-C_{e}\right) \cdot V}{m}$

where, $q_{e}$ is the equilibrium adsorption/desorption capacity $(\mathrm{mg} / \mathrm{g}) ; C_{o}$ and $C_{e}$ are the initial and equilibrium $\mathrm{Pb}(\mathrm{II})$ concentrations in the water $(\mathrm{mg} / \mathrm{l})$ respectively; $V$ is the volume of used solution (1); and ' $m$ ' is the mass of used biosorbent (g). The equilibrium data for adsorption and desorption were fitted with Langmuir, Freundlich and SIPS isotherm models. All equilibrium model parameters were evaluated and optimised using non-linear regression in MATLAB ${ }^{\circledR}$ (R2010b). The model's fitness was verified by the coefficient of determination $\left(R^{2}\right.$ : shows closeness of experimental $q_{e}$ and model prediction $q_{e}$ ), the residual root mean square error (RMSE) and the chi-square test $\left(\chi^{2}\right)$ (Hossain et al. 2012).

\section{RESULTS AND DISCUSSION}

\section{Influence of $\mathbf{p H}$}

The $p H$ value strongly influences the adsorption of metal ions from aqueous solutions. The influence of $p H$ on the adsorption of $\mathrm{Pb}$ (II) ions was is presented in Figure 1(a). The uptake of $\mathrm{Pb}$ (II) ions increases with increasing $p H$. Similar results have been reported for different biomass (Anwar et al. 2010). A sharp increase in biosorption occurred in the $p H$ range 2.5 to 4.5. The maximum biosorption was $98.5 \%$ for $\mathrm{Pb}(\mathrm{II})$ ions at $p H 6.3$; therefore, all biosorption experiments were carried out with $p H$ of 6.0-6.5. At $p H$ values higher than 6.0, metal ions precipitated and biosorption studies at these $\mathrm{pH}$ values could not be performed (Romera et al. 
2008). The decrease in removal efficiency at low $p H$ could be due to the fact that the mobility of the hydrogen $\left(\mathrm{H}^{+}\right)$ions is higher than that of the metal ions so $\mathrm{H}^{+}$reacts with active sites before adsorbing the metal ions (Akbar et al. 2010).

\section{Influence of biosorbent amount}

Optimising the doses of biosorbent for adsorption of $\mathrm{Pb}$ (II) ions was accomplished with five initial $\mathrm{Pb}$ (II) concentrations (1-15 mg/l) and 0.01 to $3 \mathrm{~g}$ doses of MLP. Figure 1(b) shows the results for $\mathrm{Pb}(\mathrm{II})$ adsorption. For the five initial $\mathrm{Pb}(\mathrm{II})$ concentrations, $10 \mathrm{mg} / \mathrm{l}$ removed more $\mathrm{Pb}$ (II) ions (98.2\%) than other concentrations. Among the doses, $0.5 \mathrm{~g}$ posed higher removal for $\mathrm{Pb}$ (II) ions. Therefore, $0.5 \mathrm{~g}$ MLP was adopted as the dose for $100 \mathrm{ml}$ of water and $10 \mathrm{mg} / \mathrm{l}$ of $\mathrm{Pb}(\mathrm{II})$ for the other studies.

\section{Effect of contact time and initial concentration}

The contact time affected the extent of adsorption of the $\mathrm{Pb}(\mathrm{II})$. Figure 1(c) shows the variation in the extent of adsorption capacity ( $\mathrm{mg} / \mathrm{g}$ ) of $\mathrm{Pb}(\mathrm{II})$ on MLP at room temperature over time for five initial $\mathrm{Pb}$ (II) concentrations. As Figure 1(c) shows, the amount of the $\mathrm{Pb}$ (II) adsorbed onto the MLP increases with time and initial $\mathrm{Pb}$ (II) concentrations, but eventually no more $\mathrm{Pb}$ (II) ions are removed from solution. The time required to attain equilibrium is termed equilibrium time; the amount of $\mathrm{Pb}$ (II) adsorbed at equilibrium time reflects the maximum adsorption capacity of the adsorbent under those operating conditions. Rapid adsorption was observed in the initial stage; this may be explained by a rapid adsorption on the outer surface of the MLP, followed by slower adsorption inside the pores. The second stage was much slower than the first, and equilibrium was reached after 5, 5, 6, 15 and $20 \mathrm{~min}$ for 10, 25, 50, 100 and $200 \mathrm{mg} / \mathrm{l}$ $\mathrm{Pb}$ (II) concentrations, respectively. This rapid kinetics has important practical implications for the development of a metal biosorption system with maple leaves.

\section{Effect of particle size}

The effect of varying MLP particle sizes on the $\mathrm{Pb}(\mathrm{II})$ adsorption rate is shown in Figure 1(d). Smaller particles $(<75 \mu \mathrm{m})$ have greater $\mathrm{Pb}$ (II) removal capacity. This is most probably due to an increase in total surface area, which provides more biosorption sites for the metal ions (Schiewer \& Volesky 2000). For large sized particles, the diffusion resistance to mass transport is relatively high and relatively less of the internal surface of the particle can be utilised for adsorption; consequently, the amount of $\mathrm{Pb}$ (II) adsorption is relatively small (Patil et al. 2011). Similar trends have been observed in adsorption of metals onto other biosorbents available in the literature (Anwar et al. 2010).

\section{Regeneration of maple leaves}


The regeneration of biosorbents is a crucial step in the reprocessing of biosorbents and recapture of valuable metals. It is also a factor in reducing operating costs for any type of water treatment. Regeneration experiments were conducted with eight eluents. The results of batch desorption and six adsorption/desorption cycles are shown in Figure 2. The $0.1 \mathrm{~N} \mathrm{H}_{2} \mathrm{SO}_{4}$ and $0.1 \mathrm{~N} \mathrm{HNO}_{3}$ eluents enabled the highest $\mathrm{Pb}$ (II) recovery at $96.8 \%$ and $97 \%$, respectively (Figure 2(a)). Adsorbed lead ions $\left(\mathrm{Pb}^{2+}\right)$ onto MLP surface could be replaced by $H^{+}$released from acids in the desorption systems and recover $\mathrm{Pb}$ (II) (Wankasi et al. 2005). Six adsorption and desorption cycles were run with $0.1 \mathrm{~N} \mathrm{H}_{2} \mathrm{SO}_{4}$ (Figure 2(b)). It was found that the MLP could be reused for five cycles with only minor loss of adsorption efficiency.

\section{Biosorption thermodynamics}

Energy changes occur during biosorption processes. Gibbs free energy $\left(\Delta G^{o}\right)$ can be calculated as follows:

$$
\Delta G^{o}=-R T \ln K_{e q}
$$

where $T$ is the absolute temperature $\left({ }^{\circ} \mathrm{K}\right)$ and ' $R$ ' is the gas constant $(8.314 \mathrm{~J} / \mathrm{mol} \mathrm{K})$. In the biosorption of heavy metals, the equilibrium constant is defined as:

$$
K_{e q}=\frac{q_{e}}{C_{e}}
$$

where $q_{e}$ is the concentration of adsorbed $\mathrm{Pb}(\mathrm{II})$ ions on the biosorbent at equilibrium, and $C_{e}$ is the $\mathrm{Pb}$ (II) concentration in the solution at equilibrium. Determination of the equilibrium constant depends on the isotherm equation used to determine the equilibrium constant of $\mathrm{Pb}$ (II) biosorption by maple leaves.

Langmuir isotherm equation (eq.6) was used to calculate $K_{e q}$ values from the biosorption of $\mathrm{Pb}(\mathrm{II})$ ions on MLP and the corresponding values of $\Delta G^{o}$ of biosorption were determined at different experimental temperatures $\left(293-343{ }^{\circ} \mathrm{K}\right)$. The degree of spontaneity of the biosorption process was judged from the corresponding Gibbs free energy; a higher negative value reflects a more energetically favourable biosorption. In addition, the equilibrium constant can be expressed in terms of enthalpy change of biosorption $\left(\Delta H^{o}\right)$ and entropy change of biosorption $\left(\Delta S^{\circ}\right)$ as functions of temperature, following the van't Hoff equation:

$$
\ln K_{e q}=\frac{\Delta S^{\circ}}{R}-\frac{\Delta H^{\circ}}{R T}
$$

where $\Delta H^{o}$ and $\Delta S^{o}$ are obtained from the slope and intercept of a van't Hoff plot of $\ln \left(K_{e q}\right)$ versus $1 / T$.

Table 1 shows the thermodynamic values for the $\mathrm{Pb}(\mathrm{II})$ biosorption process using the Langmuir isotherm for determining $K_{e q}$ values. The negative value of $\Delta G^{o}$ showed the 
spontaneous nature of $\mathrm{Pb}(\mathrm{II})$ biosorption onto MLP. The negative enthalpy $(-0.321 \mathrm{~kJ} / \mathrm{mol})$ $\Delta H^{o}$ suggested the exothermic nature of biosorption, whereas positive values $(8.0735 \mathrm{~kJ} / \mathrm{mol}$ $\mathrm{K})$ of $\Delta S^{o}$ showed the increasing randomness at the MLP-Pb(II) solution interface during the biosorption process (Dursun \& Kalayci 2005).

\section{Biosorption kinetics}

The parameters of the biosorption models were determined by non-linear regression for kinetic tests performed under different initial $\mathrm{Pb}$ (II) concentrations $(10,50$ and $100 \mathrm{mg} / \mathrm{l}$ at $\mathrm{pH} 6.0-6.5$ - see Figure 3); they are presented in Table 2. To confirm these results, pseudo-first-order, pseudo-second-order and intraparticle diffusion models were used to calculate the specific $\mathrm{Pb}$ (II) adsorption from the aqueous solution. The results, depicted in Figure 3, clearly show that the initial sorption of $\mathrm{Pb}$ (II) ions occurred very rapidly in all biosorption experiments, with most of the $\mathrm{Pb}(\mathrm{II})$ uptake occurring within the first few minutes of contact, and reached equilibrium after 20-30 minutes, suggesting that available sites on the biosorbent are the limiting factor of the biosorption process. The rapid kinetics observed for $\mathrm{Pb}(\mathrm{II})$ removal by MLP has substantial practical importance, because the kinetics will facilitate smaller reactor volumes, ensuring efficiency and economy (Günay et al. 2007).

Table 2 shows the predicted kinetic parameters for $\mathrm{Pb}(\mathrm{II})$ adsorption and desorption processes for three models. The adsorption and desorption kinetics data were well fitted with all models $\left(R^{2}>0.923\right.$, Figure 3$)$. Specifically, the adsorption and desorption data showed better fitness with the pseudo-second-order model than the pseudo-first-order model (Table 3), implying $\mathrm{Pb}$ (II) ion adsorption was the rate-controlling step (Ho 2004). Higher fitness (high $R^{2}$ and low NSD and ARE values) for the pseudo-second-order model (Table 2), obtained from both adsorption and desorption process for the three $\mathrm{Pb}$ (II) concentrations (10, 50 and 100 $\mathrm{mg} / \mathrm{l}$ ), also reinforced the proposition and argument derived from FTIR spectra. Experimental and calculated values of equilibrium adsorption/desorption capacities $\left(q_{e}\right)$ from the pseudosecond-order model are more similar than those from the pseudo-first-order model.

Significantly, low NSD and ARE values (Table 2) were obtained from pseudo-second-order models for both adsorption and desorption processes. These results suggest that the adsorption/desorption system follows the pseudo-second-order kinetics, which further implies that adsorption is the rate-controlling step (Ho 2004).

Multi-linear plot was found for both adsorption and desorption of $\mathrm{Pb}(\mathrm{II})$ onto the MLP biosorbent (Figure 4). Two clear steps were found in the plots which are definitely a general type of intraparticle diffusion type plot (shown as straight line in Figure 4). The first stage could also be recognised as boundary layer diffusion, while the second stage might be due to 
intraparticle diffusion effects (Srihari \& Das 2008). In the present study, the rate constant $\left(k_{p}\right)$ for adsorption (2.089 to $16.983 \mathrm{mg} / \mathrm{g} \sqrt{ } \mathrm{min}$ ) and desorption ( 1.377 to $14.299 \mathrm{mg} / \mathrm{g} \vee \mathrm{min}$ ) increased with increased initial $\mathrm{Pb}$ (II) concentration (Table 3). Therefore, the slope of the linear portion in the second stage may be described as a rate parameter $\left(k_{p}\right)$ and a characteristic of the adsorption and desorption rate in the region (where intraparticle diffusion occurs) which has previously been reported in the literature to be the rate-limiting factor (Hanafiah et al. 2006).

\section{Biosorption equilibrium}

Equilibrium isotherms are used to calculate the maximum capacity of the biosorbent (MLP) for $\mathrm{Pb}$ (II) ions. The Langmuir, Freundlich and Sips isotherms are three of the most common types of equilibrium isotherms for describing adsorption systems.

\section{Langmuir isotherm}

The most widely used adsorption isotherm is the Langmuir model. A basic assumption of the Langmuir theory is that adsorption takes place at specific homogeneous sites within the adsorbent. The saturated monolayer isotherm can be represented as (Langmuir 1918):

$q_{e}=\frac{q_{m} K_{L} C_{e}}{1+K_{L} C_{e}}$

where $C_{e}$ is the equilibrium concentration $(\mathrm{mg} / \mathrm{l}), q_{e}$ is the amount of metal ion adsorbed $(\mathrm{mg} / \mathrm{g}), q_{m}$ is the $q_{e}$ for a complete monolayer $(\mathrm{mg} / \mathrm{g})$ and a constant related to adsorption capacity, and $K_{L}$ is the constant related to the affinity of the binding sites and the energy of adsorption (1/mg).

\section{Freundlich isotherm}

Freundlich devised an empirical model based on adsorption on a heterogeneous surface and multilayer adsorption, which is given by (Thomas et al. 1997):

$q_{e}=K_{F} C_{e}^{1 / n}$

where $q_{e}$ is the quantity of metal ions adsorbed per unit mass of the adsorbent, $C_{e}$ the equilibrium solution concentration, and $K_{F}$ and $n$ are Freundlich equilibrium coefficients. For favourable adsorption, $0<n<1$, while $n>1$ represents unfavourable adsorption, and $n=1$ indicates linear adsorption. If $n=0$, the adsorption process is irreversible (Abia \& Asuquo 2006).

\section{Sips isotherm}

An empirical isotherm equation was proposed by Sips, which is often expressed as (Sips 1948):

$$
q_{e}=\frac{K_{s} C_{e}^{\beta_{s}}}{1+\alpha_{s} C_{e}^{\beta_{s}}}
$$


where $q_{e}$ is the amount of metal ions adsorbed per unit mass of the adsorbent, $C_{e}$ the equilibrium solution concentration and; $\alpha_{s}$ and $\beta_{s}$ is the Sips constants.

The equilibrium data at $0.05,0.5$ and $1 \mathrm{~g} / 100 \mathrm{ml}$ of MLP are shown in Figure 5 for both adsorption and desorption. A non-linear regression model was used to determine the bestfitting isotherm. The Langmuir, Freundlich and Sips parameters at different initial $\mathrm{Pb}(\mathrm{II})$ concentrations, including their coefficients of determination $\left(R^{2}\right), \chi^{2}$ and $R M S E$, presented in Table 3, demonstrate that the Langmuir equation provides the best fitness of the experimental data. The monolayer capacity of the MLP was $50.26 \mathrm{mg} / \mathrm{g}$ from this isotherm while its desorption capacity was $60.26 \mathrm{mg} / \mathrm{g}$ for $1 \mathrm{~g}$ doses. The monolayer capacity, $q_{m}$, for Langmuir increased from 22.79 to $27.41 \mathrm{mg} / \mathrm{g}$ for an increase in solution temperature from 25 to $60{ }^{\circ} \mathrm{C}$.

The other mono-component Langmuir constant, $K_{L}$, indicates the affinity for the binding of $\mathrm{Pb}$ (II) ions. The essential characteristics of the Langmuir isotherm are described by the separation factor or equilibrium constant $R_{L}$, which is defined as $R_{L}=1 /\left(1+K_{L} C_{o}\right.$ ) (where $C_{o}$ is the initial concentration of $\mathrm{Pb}(\mathrm{II})$, and $K_{L}$ is its Langmuir constant). This indicates the nature of adsorption as $R_{L}>1$ (unfavourable), $0<R_{L}<1$ (favourable), $R_{L}=0$ (irreversible), and $R_{L}=1$ (linear).

The values of $R_{L}$ in the present investigation were below 1.0 for both adsorption and desorption of $\mathrm{Pb}$ (II) from MLP biosorbent, showing that the adsorption/desorption of $\mathrm{Pb}$ (II) is very favourable. The values of $1 / n$ from Freundlich models were also found to be less than unity for both adsorption and desorption processes, which suggests favourable adsorption and desorption behaviours of $\mathrm{Pb}(\mathrm{II})$ onto MLP.

As Table 3 shows, the Sips isotherm exhibits higher $R^{2}(0.998-0.994)$ values and lower $\chi^{2}$ and RMSE values, viewing that this model fitted considerably better than the Freundlich and Langmuir isotherms. Similar results were found from desorption of $\mathrm{Pb}(\mathrm{II})$ from MLP. Therefore, the Sips isotherm can also be used for describing the biosorption and desorption behaviour of $\mathrm{Pb}$ (II) ions on MLP. However, this isotherm contains three parameters and the values of $\beta_{S}$ are close to 1 , which confirms its tendency towards the Langmuir isotherm. In Table 3, the calculated monolayer capacity, $K_{S}$ from the Sips isotherm was compared with those of the other models prediction and this value is lower than experimental and predicted values of other models (Table 3).

\section{Biosorbent characteristics and biosorption mechanism for $\mathbf{P b}(\mathrm{II})$}

It is thought that various metal-binding mechanisms are involved in the biosorption process, including chemical or physical biosorption, ion exchange, surface adsorption and adsorption complexation (Sangi et al. 2008). The MLP-Pb(II) adsorption mechanisms associated for 
higher $\mathrm{Pb}(\mathrm{II})$ removal are explained here on the basis of FTIR, SEM, X-ray mapping and the results obtained from equilibrium and kinetic studies.

FTIR spectra show (Figure 6) that MLP has different functional groups. These groups are ionisable and can react with $\mathrm{H}^{+}$or cations in aqueous solution (Gulnaz et al. 2005). The major functional groups found from spectra (Figure 6) were $\mathrm{O}-\mathrm{H}$ stretch-free hydroxyl for alcohols/phenols $\left(3624.54 \mathrm{~cm}^{-1}\right), O-H$ stretch for carboxylic acids (between 3,300 and 2,500 $\left.\mathrm{cm}^{-1}\right), C-N$ stretch for aliphatic amines $\left(1024.25 \mathrm{~cm}^{-1}\right), C-O$ stretch for alcohols/carboxylic acids/esters/ethers (between 1,320 and $1,000 \mathrm{~cm}^{-1}$ ), $=C-H$ bend for alkanes (between 1,000 and $650 \mathrm{~cm}^{-1}$ ) and $\mathrm{C}-\mathrm{H}$ “OOH” for aromatics $\left(817.85 \mathrm{~cm}^{-1}\right.$ ) (Pons et al. 2004). Functional groups, such as hydroxyl and carboxyl groups, are able to bind with $\mathrm{Pb}(\mathrm{II})$ ions (Ricordel et al. 2001).

The metals adsorption capacity, surface properties, active functional groups of biosorbent can be explored from characterisations. The surface properties of the MLP biosorbent were examined by the BET test and measured surface properties are tabulated in Table 1. The BET surface area of the MLP biosorbent is $10.94 \mathrm{~m}^{2} / \mathrm{g}$, which is comparable with the measurements for the biosorbents produced from agricultural wastes for $\mathrm{Pb}$ (II) removal (Table 4). The total pore volume of the MLP biosorbent was $0.02 \mathrm{~cm}^{3} / \mathrm{g}$ and most of the pore volume was mesopore (100\%). In addition, the mean micropore and mesopore sizes of the MLP biosorbent were $8.71 \AA$ and $41.46 \AA$ (Table 4), respectively, suggesting that this biosorbent falls within the mesopore region based on IUPAC classifications.

The surface structure of the MLP biosorbent was analysed using a SEM before and after $\mathrm{Pb}$ (II) ion adsorption (Figure 7). The micrographs clearly reveal the presence of asymmetric pores and particles in the MLP biosorbent (Figure 7(a)), which signifies high internal surface area that could be responsible for high $\mathrm{Pb}$ (II) adsorption. After $\mathrm{Pb}$ (II) adsorption, the micrographs show (Figure 7(b)) that the pores were filled and dense in structure - probably due to adsorbed $\mathrm{Pb}(\mathrm{II})$ on the internal layers of particles of MLP. The X-ray mapping of the maple leaves (Figure 7(c)) showed the presence of adsorbed $\mathrm{Pb}$ (II) ions in the surface of the biosorbent, similar to the findings of spectral analysis (Figure 6). The XRD spectrum of maple leaves (Figures 7(d) and 7(e)) shows the constituent elements of maple leaves.

Contrasting to hints of FTIR analysis and activation energy evaluation, the high $R^{2}, \chi^{2}$ and RMSE values for the Langmuir isotherm and high $R^{2}, N S D$ and ARE values for the pseudosecond-order kinetic model advise reasonable fixed values for MLP's $\mathrm{Pb}$ (II) biosorption, which could correspond to a chelating bond between the $\mathrm{Pb}(\mathrm{II})$ ion and carboxylic groups. However, the high $R^{2}$ values of the Freundlich isotherm suggest other mechanisms (such as physisorption 
or chemisorption) are involved, and that a degree of heterogeneity is possible for ionic species involved in the solution and on the surface. Therefore, the analyses of the results make it very difficult to assign a definite mechanism for the sorption of $\mathrm{Pb}(\mathrm{II})$ ions onto maple leaves. It is possible that a combination of adsorption mechanisms (chelating bond, physisorption or chemisorption) is involved in the uptake of $\mathrm{Pb}$ (II) ions onto maple leaves.

\section{Comparison of adsorption capacity}

The $\mathrm{Pb}$ (II) adsorption capacities of MLP and 11 other adsorbents were compared; the results are shown in Table 5. The $\mathrm{Pb}$ (II) adsorption capacity of MLP is higher than all other tested biomass, with the exception of tea leaves. Nevertheless, the adsorption capacity of MLP can be increased by activating the adsorbent.

\section{CONCLUSIONS}

Maples leaves are feasible and effective biosorbent for the removal of $\mathrm{Pb}$ (II) from aqueous solutions in the context of efficiency, availability in some cold countries and low cost, although these are laboratory findings. Biosorption kinetics follows a pseudo-second-order model, and the Langmuir isotherm model best reproduces the experimental data. SEM and X-ray mapping confirmed the presence of $\mathrm{Pb}(\mathrm{II})$ ions on the MLP's biomass surface. Thermodynamic properties indicate that the $\mathrm{Pb}(\mathrm{II})$ biosorption process is spontaneous and exothermic in nature. Experimental results suggest that $p H$, doses, initial $\mathrm{Pb}(\mathrm{II})$ concentration, contact time and particle affect the biosorption process. Small particle size $(<75 \mu \mathrm{m})$ confers higher $\mathrm{Pb}(\mathrm{II})$ biosorption than larger sizes. Quick equilibrium time (5-20 mins) for different initial $\mathrm{Pb}$ (II) concentrations suggests maple leaves have practical potential as an alternative metal adsorbent. The MLP biosorbent was successfully used in five successive adsorption/desorption cycles. MLP's monolayer capacity of $\mathrm{Pb}$ (II) biosorption is comparable to those of other biosorbents reported in the literature.

\section{ACKNOWLEDGEMENTS}

This research was supported by Research Theme of Wastewater Treatment and Reuse Technologies for Sustainable Water, Centre for Technology in Water and Wastewater (CTWW), School of Civil and Environmental Engineering, University of Technology, Sydney (UTS) and UTS International Postgraduate Research Scholarship.

\section{REFERENCES}

Abia, A. A. \& Asuquo, E. D. 2006 Pb (II) and Nickel (II) adsorption kinetics from aqueous metal solutions using chemically modified and unmodified agricultural adsorbents. Afr.

J. Biotechnol. 5, 1475-1482. 
Akbar, S., Shah, T. H., Anwar, M. \& Khan, M. 2010 A study of cobalt ions removal from aqueous solutions by sodium X-zeolite. J. Chem. Soc. Pakistan 32, 331-337.

Amuda, O. \& Alade, A. 2006 Coagulation/flocculation process in the treatment of abattoir wastewater. Desalination 196, 22-31.

Anwar, J., Shafique, U., Waheed uz, Z., Salman, M., Dar, A. \& Anwar, S. 2010 Removal of $\mathrm{Pb}(\mathrm{II})$ and $\mathrm{Cd}(\mathrm{II})$ from water by adsorption on peels of banana. Biores. Technol. 101, $1752-1755$.

Blázquez, G., Martín-Lara, M. A., Tenorio, G. \& Calero, M. 2011 Batch biosorption of Pb(II) from aqueous solutions by olive tree pruning waste: Equilibrium, kinetics and thermodynamic study. Chem. Eng. J. 168, 170-177.

Demirbas, A. 2008 Heavy metal adsorption onto agro-based waste materials: A review. $J$. Hazard. Mater. 157, 220-229.

Dursun, A. Y. \& Kalayci, Ç. S. 2005 Equilibrium, kinetic and thermodynamic studies on the adsorption of phenol onto chitin. J. Hazard. Mater. 123, 151-157.

El-Ashtoukhy, E. S. Z., Amin, N. K. \& Abdelwahab, O. 2008 Removal of Pb (II) and copper (II) from aqueous solution using pomegranate peel as a new adsorbent. Desalination 223, 162-173.

Günay, A., Arslankaya, E. \& Tosun, İ. 2007 Pb removal from aqueous solution by natural and pretreated clinoptilolite: Adsorption equilibrium and kinetics. J. Hazard. Mater. 146, $362-371$.

Gulnaz, O., Saygideger, S. \& Kusvuran, E. 2005 Study of Cu(II) biosorption by dried activated sludge: effect of physico-chemical environment and kinetics study. J. Hazard. Mater. 120, 193-200.

Hanafiah, M. A. K. M., Ngah, W. S. W., Ibrahim, S. C., Zakaria, H. \& Ilias, W. A. H. W. 2006 Kinetics and thermodynamic study of $\mathrm{Pb}$ adsorption from aqueous solution onto rubber (Hevea brasiliensis) leaf powder. J. Appl. Sci. 6, 2762-2767.

Ho, Y. S. 2004 Comment on "Removal of copper from aqueous solution by aminated and protonated mesoporous aluminas: kinetics and equilibrium,” by S. Rengaraj, Y. Kim, C.K. Joo, and J. Yi. J. Colloid. Interf. Sci. 276, 255-258.

Hossain, M. A., Ngo, H. H., Guo, W. S. \& Setiadi, T. 2012 Adsorption and desorption of copper(II) ions onto garden grass. Biores. Technol. 121, 386-395.

Ibrahim, M. N. M., Ngah, W. S. W., Norliyana, M. S., Daud, W. R. W., Rafatullah, M., Sulaiman, O. \& Hashim, R. 2010 A novel agricultural waste adsorbent for the removal of $\mathrm{Pb}$ (II) ions from aqueous solutions. J. Hazard. Mater. 182, 377-385. 
Kay, Y., Aksakal, Ö. \& Ucun, H. 2009 Biosorption of Pb(II) and zinc(II) from aqueous solutions by Nordmann fir (Abies nordmanniana (Stev.) Spach. subsp. nordmanniana) cones. Acta Chim. Slov. 56, 451-456.

Kobya, M., Demirbas, E., Senturk, E. \& Ince, M. 2005 Adsorption of heavy metal ions from aqueous solutions by activated carbon prepared from apricot stone. Biores. Technol. 96, $1518-1521$.

Langmuir, I. 1918 The adsorption of gases on plane surfaces of glass, mica and platinum. $J$. Am. Chem. Soc. 40, 1361-1403.

Li, Q., Zhai, J., Zhang, W., Wang, M. \& Zhou, J. 2007 Kinetic studies of adsorption of Pb (II), $\mathrm{Cr}$ (III) and $\mathrm{Cu}$ (II) from aqueous solution by sawdust and modified peanut husk. $J$. Hazard. Mater. 141, 163-167.

Martínez, M., Miralles, N., Hidalgo, S., Fiol, N., Villaescusa, I. \& Poch, J. 2006 Removal of $\mathrm{Pb}(\mathrm{II})$ and cadmium(II) from aqueous solutions using grape stalk waste. J. Hazard. Mater. 133, 203-211.

Okoye, A. I., Ejikeme, P. M. \& Onukwuli, O. D. 2010 Pb removal from wastewater using fluted pumpkin seed shell activated carbon: Adsorption modeling and kinetics. Int. J. Environ. Sci. Technol. 7, 793-800.

Patil, S., Deshmukh, V., Renukdas, S. \& Pate, N. 2011 Kinetics of adsorption of crystal violet from aqueous solutions using different natural materials. Int. J. Environ. Sci. 1, 11161134.

Pons, M.-N., Bonté, S. L. \& Potier, O. 2004 Spectral analysis and fingerprinting for biomedia characterisation. J. Biotechnol. 113, 211-230.

Qaiser, S., Saleemi, A. R. \& Umar, M. 2009 Biosorption of Pb(III) and chromium(VI) on groundnut hull: Equilibrium, kinetics and thermodynamics study. Electron. J.

Biotechnol. 12, 1-17.

Rafatullah, M., Sulaiman, O., Hashim, R. \& Ahmad, A. 2009 Adsorption of copper (II), chromium (III), nickel (II) and $\mathrm{Pb}$ (II) ions from aqueous solutions by meranti sawdust. J. Hazard. Mater. 170, 969-977.

Rahman, M. S. \& Islam, M. R. 2009 Effects of $\mathrm{pH}$ on isotherms modeling for $\mathrm{Cu}(\mathrm{II})$ ions adsorption using maple wood sawdust. Chem. Eng. J. 149, 273-280.

Riaz, M., Nadeem, R., Hanif, M. A., Ansari, T. M. \& Rehman, K. U. 2009 Pb(II) biosorption from hazardous aqueous streams using Gossypium hirsutum (Cotton) waste biomass. $J$. Hazard. Mater. 161, 88-94. 
Ricordel, S., Taha, S., Cisse, I. \& Dorange, G. 2001 Heavy metals removal by adsorption onto peanut husks carbon: characterization, kinetic study and modeling. Sep.Purif. Technol. 24, 389-401.

Romera, E., Gonzalez, F., Ballester, A., Blazquez, M. L. \& Munoz, J. A. 2008 Biosorption of $\mathrm{Cd}, \mathrm{Ni}$, and Zn with mixtures of different types of algae. Environ. Eng. Sci. 25, 9991008 .

Sangi, M. R., Shahmoradi, A., Zolgharnein, J., Azimi, G. H. \& Ghorbandoost, M. 2008 Removal and recovery of heavy metals from aqueous solution using Ulmus carpinifolia and Fraxinus excelsior tree leaves. J. Hazard. Mater. 155, 513-522.

Santorufo, L., Van Gestel, C. A. M. \& Maisto, G. 2012 Ecotoxicological assessment of metalpolluted urban soils using bioassays with three soil invertebrates. Chemosphere $\mathbf{8 8}$, $418-425$.

Sar1, A. \& Tuzen, M. 2008 Biosorption of Pb(II) and Cd(II) from aqueous solution using green alga (Ulva lactuca) biomass. J. Hazard. Mater. 152, 302-308.

Schiewer, S. \& Volesky, B. 2000 Biosorption processes for heavy metal removal. In: Lovley, D. R. (Ed.), Environmental Microbe-Metal Interactions. ASM Press, Washington DC, pp. 329-362.

Sekar, M., Sakthi, V. \& Rengaraj, S. 2004 Kinetics and equilibrium adsorption study of $\mathrm{Pb}(\mathrm{II})$ onto activated carbon prepared from coconut shell. J. Coll. Interf. Sci. 279, 307-313.

Sips, R. 1948 On the structure of a catalyst surface. J. Chem. Physics 16, 490-495.

Srihari, V. \& Das, A. 2008 The kinetic and thermodynamic studies of phenol-sorption onto three agro-based carbons. Desalination 225, 220-234.

Thomas, H., Yong, R. \& Hashm, A. 1997 Numerical modelling of contaminant transport in unsaturated soil. In: Proc. Int. Conf on Geoenviron. Engin., Cardiff, 278-283.

Volesky, B. \& Holan, Z. 1995 Biosorption of heavy metals. Biotechnol. Prog. 11, 235-250.

Wankasi, D., Horsfall, M. \& Spiff, A. I. 2005 Retention of Pb (II) ion from aqueous solution by Nipah palm (Nypa fruticans Wurmb) petiole biomass. J. Chilean Chem. Soc. 50, 691-696.

Witek-Krowiak, A., Krysiak, M., Modelski, S., Eckert, K. \& Kloczkowski, P. 2010

Biosorption of cationic dyes from aqueous solutions with maple leaves. Chem. Process Eng. 31, 825-837. 
Table 1 | Thermodynamic parameters for the adsorption of $\mathrm{Pb}(\mathrm{II})$ by maple leaves

\begin{tabular}{llllll}
\hline Temp. $\left({ }^{\circ} \mathbf{K}\right)$ & $\boldsymbol{q}_{\boldsymbol{m}}(\mathbf{m g} / \mathbf{g})$ & $\boldsymbol{K}_{\boldsymbol{e q}}$ & $\begin{array}{l}\Delta \boldsymbol{G}^{\boldsymbol{o}} \\
(\mathbf{k J} / \mathbf{m o l})\end{array}$ & $\begin{array}{l}\Delta \boldsymbol{H}^{\boldsymbol{o}} \\
(\mathbf{k J} / \mathbf{m o l})\end{array}$ & $\begin{array}{l}\Delta \boldsymbol{S}^{\boldsymbol{o}} \\
\left(\mathbf{J} / \mathbf{m o l}{ }^{\circ} \mathbf{K}\right)\end{array}$ \\
\hline 293 & 7.138 & 1.908 & -1.574 & -0.321 & 8.0735 \\
303 & 5.774 & 1.691 & -1.324 & & \\
313 & 5.893 & 1.896 & -1.665 & & \\
323 & 1.229 & 2.749 & -2.716 & & \\
343 & 1.753 & 2.708 & -2.841 & & \\
\hline
\end{tabular}


Table 2 | Kinetics modelling of $\mathrm{Pb}$ (II) adsorption and desorption onto maple leaves

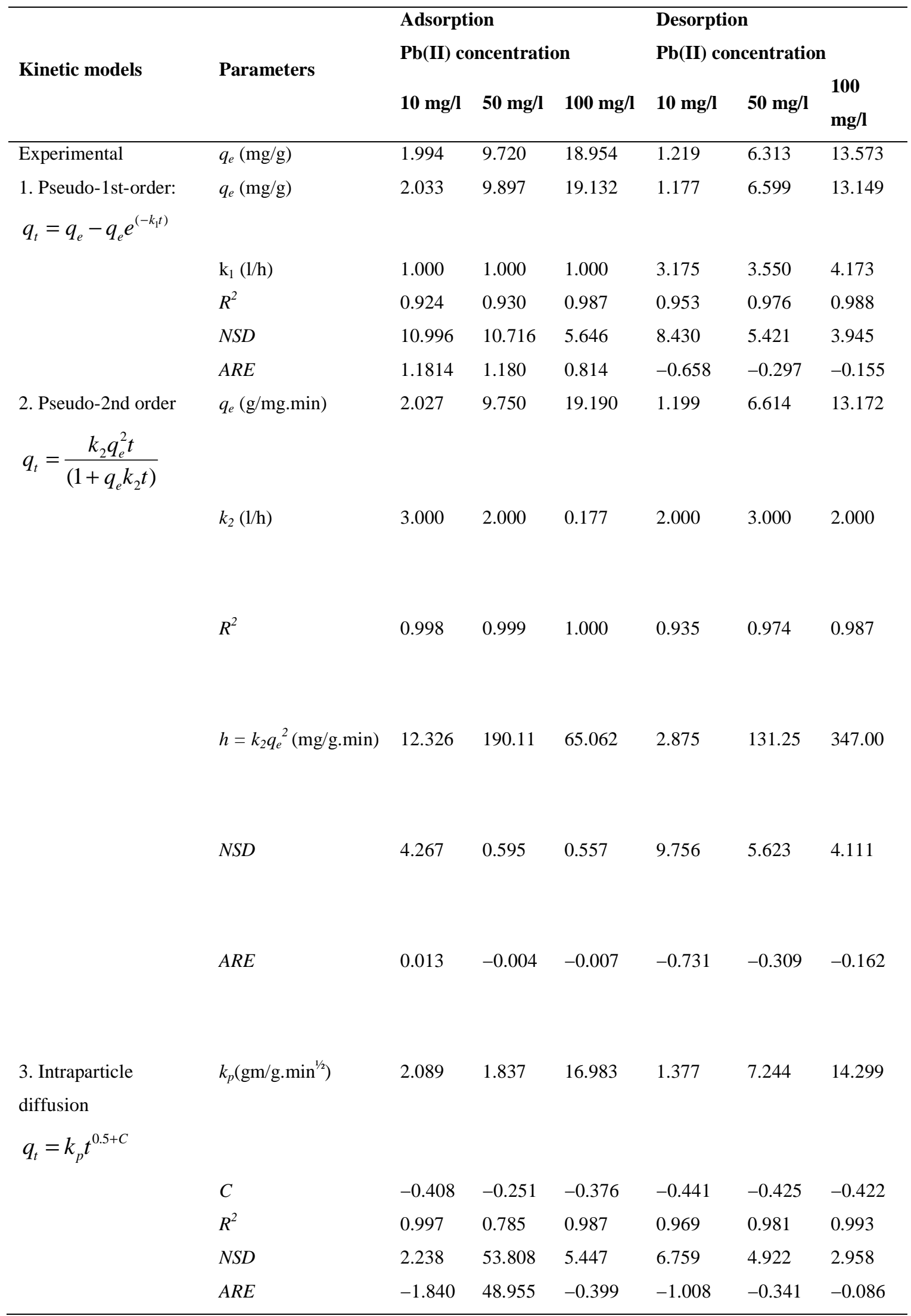


Table 3 The prediction of isotherm models for adsorption and desorption of $\mathrm{Pb}(\mathrm{II})$ on maple leaves

\begin{tabular}{|c|c|c|c|c|c|c|c|}
\hline \multirow{2}{*}{ Isotherm models } & \multirow{2}{*}{ Parameters } & \multicolumn{3}{|c|}{ Adsorption Doses } & \multicolumn{3}{|c|}{ Desorption Doses } \\
\hline & & $0.05 \mathrm{~g}$ & $0.5 \mathrm{~g}$ & $1 \mathrm{~g}$ & $0.05 g$ & $0.5 \mathrm{~g}$ & $1 \mathrm{~g}$ \\
\hline Experimental & $q_{m}(\mathrm{mg} / \mathrm{g})$ & 125.95 & 66.722 & 50.267 & 150.68 & 60.26 & 40.056 \\
\hline \multirow{8}{*}{$\begin{array}{l}\text { 1. Langmuir } \\
q_{e}=\frac{q_{m} K_{L} C_{e}}{1+K_{L} C_{e}}\end{array}$} & $q_{m}$ & 165.06 & 85.993 & 43.857 & 136.840 & 82.127 & 50.05 \\
\hline & & & & & & & \\
\hline & $K_{L}$ & 0.094 & 0.013 & 0.073 & 0.016 & 0.003 & 0.001 \\
\hline & $R_{L}$ & $0.02-0.99$ & $0.27-0.98$ & $0.12-0.97$ & $0.98-0.99$ & 0.84-0.99 & $0.83-0.99$ \\
\hline & $R^{2}$ & 0.966 & 0.992 & 0.994 & 0.999 & 0.998 & 0.997 \\
\hline & $\Delta^{o} G$ & -5.75 & -10.55 & -6.371 & -10.12 & -14.27 & -17.44 \\
\hline & $\chi^{2}$ & 282.07 & 0.849 & 1.011 & 0.0041 & 0.0075 & 0.0007 \\
\hline & $R M S E$ & 12.47 & 2.060 & 1.212 & 0.1591 & 0.268 & 0.5624 \\
\hline \multirow{6}{*}{$\begin{array}{l}\text { 2. Freundlich } \\
q_{e}=K_{F} C_{e}^{1 / n}\end{array}$} & $K_{F}$ & 44.663 & 3.581 & 5.687 & 2.000 & 0.294 & 1.076 \\
\hline & & & & & & & \\
\hline & $n$ & 4.293 & 1.810 & 2.247 & 1.000 & 1.104 & 1.795 \\
\hline & $R^{2}$ & 0.963 & 0.982 & 0.962 & 1.000 & 0.998 & 0.917 \\
\hline & $\chi^{2}$ & 58.615 & 12.795 & 17.671 & $1.52 \times 10^{-9}$ & 0.284 & 14.781 \\
\hline & $R M S E$ & 13.001 & 3.207 & 2.961 & $2.11 \times 10^{-5}$ & 0.239 & 2.971 \\
\hline \multirow{7}{*}{$\begin{array}{l}\text { 3. SIPS } \\
q_{e}=\frac{K_{s} C_{e}^{\beta_{s}}}{1+\alpha_{s} C_{e}^{\beta_{s}}}\end{array}$} & Ks & 45.442 & 2.014 & 3.620 & 2.000 & 0.252 & 0.134 \\
\hline & & & & & & & \\
\hline & $\alpha_{S}$ & 0.2118 & 0.0179 & 0.079 & 0.000 & 0.003 & 0.001 \\
\hline & $\beta_{S}$ & 0.4787 & 0.8046 & 0.079 & 1.000 & 0.913 & 0.926 \\
\hline & $R^{2}$ & 0.991 & 0.988 & 0.994 & 1.000 & 1.000 & 1.000 \\
\hline & $\chi^{2}$ & 8.192 & 1.656 & 1.253 & $1.8 \times 10^{-6}$ & 0.012 & 0.005 \\
\hline & $R M S E$ & 0.644 & 0.069 & 0.231 & $1.4 \times 10^{-13}$ & 0.004 & 0.014 \\
\hline
\end{tabular}


Table 4 | BET characteristics biosorbent produced from maple leaves

\begin{tabular}{lll}
\hline Parameter of maple leaves & Methods & Values \\
\hline 1. Surface area & BET surface area & $10.94 \mathrm{~m}^{2} / \mathrm{g}$ \\
& Langmuir surface area & $-38.12 \mathrm{~m}^{2} / \mathrm{g}$ \\
2. Pore area & DR method & $3.53 \mathrm{~m}^{2} / \mathrm{g}$ \\
i. Micropore area & t-plot (statistical thickness $=$ & $-2.36 \mathrm{~m}^{2} / \mathrm{g}$ \\
& 3.50 7.00) & \\
Horvath-Kawazoe method & $0.58 \mathrm{~m}^{2} / \mathrm{g}$ \\
ii. Mesopore area & BJH adsorption & $14.88 \mathrm{~m}^{2} / \mathrm{g}$ \\
3. Pore volume & BJH desorption & $26.31 \mathrm{~m}^{2} / \mathrm{g}$ \\
i. Micropore volume & DR method & \\
& t-plot (statistical thickness $=$ & $-0.00 \mathrm{~cm}^{3} / \mathrm{g}$ \\
& $3.50 \sim 7.00)$ & \\
Horvath-Kawazoe method & $0.00 \mathrm{~cm}^{3} / \mathrm{g}$ \\
ii. Mesopore volume & BJH adsorption & $0.02 \mathrm{~cm}^{3} / \mathrm{g}$ \\
BJH desorption & $0.04 \mathrm{~cm}^{3} / \mathrm{g}$ \\
4. Pore size & DR method & $8.71 \AA$ \\
i. Micropore size & t-plot (statistical thickness $=$ & $36.14 \AA$ \\
& $3.50 \sim 7.00)$ & $14.38 \AA$ \\
& Horvath-Kawazoe method & $41.46 \AA$ \\
& BJH adsorption & $32.44 \AA$ \\
\hline
\end{tabular}


Table 5 | Comparison of $\mathrm{Pb}(\mathrm{II})$ removal by various low cost adsorbents

\begin{tabular}{|c|c|c|c|c|}
\hline Name & $\begin{array}{l}\text { Adsorption capacity } \\
q_{m}(\mathrm{mg} / \mathrm{g})\end{array}$ & $p H$ & $\begin{array}{l}\mathrm{C}_{0}{ }^{*} \\
(\mathrm{mg} / \mathrm{l})\end{array}$ & Reference \\
\hline \multicolumn{5}{|l|}{ Normal powder form } \\
\hline Maple leaves & 50.267 & $6-6.5$ & $1-500$ & This study \\
\hline $\begin{array}{l}\text { Modified empty fruit brunch of } \\
\text { palm oil }\end{array}$ & 46.72 & 5.5 & $5-100$ & (Ibrahim et al. 2010) \\
\hline Meranti sawdust & 34.24 & 6.0 & $1-200$ & (Rafatullah et al. 2009) \\
\hline Olive tree pruning waste & 33.39 & 5.0 & $10-1000$ & (Blázquez et al. 2011) \\
\hline Nordmann fir & 29.35 & 6.0 & $5-100$ & (Kay et al. 2009) \\
\hline Groundnut hull & 31.54 & 5.0 & $10-1000$ & (Qaiser et al. 2009) \\
\hline Green alga (Ulva lactuca) biomass & 34.7 & 5.0 & $10-400$ & (Sarı \& Tuzen 2008) \\
\hline \multicolumn{5}{|l|}{ (Gossypium hirsutum) } \\
\hline Modified peanut sawdust & 29.1 & 4.0 & $5-50$ & (Li et al. 2007) \\
\hline Grape stalks & 49.7 & 5.5 & $5-500$ & (Martínez et al. 2006) \\
\hline \multicolumn{5}{|l|}{$A C *$ form } \\
\hline $\mathrm{AC}$ (apricot stone) & 22.85 & 6.0 & $1-200$ & (Kobya et al. 2005) \\
\hline AC (coconut shell) & 26.50 & 4.5 & $10-50$ & (Sekar et al. 2004) \\
\hline
\end{tabular}

* $\mathrm{C}_{0}$ : initial $\mathrm{Pb}(\mathrm{II})$ concentration; $* \mathrm{AC}=$ activated carbon 

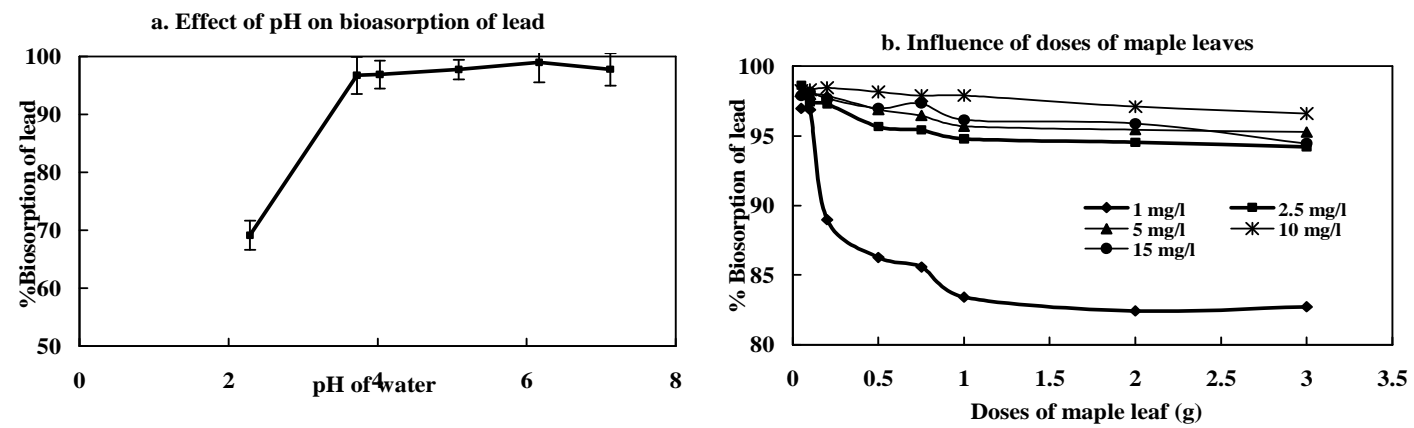

C. Influence of contact time and initial lead
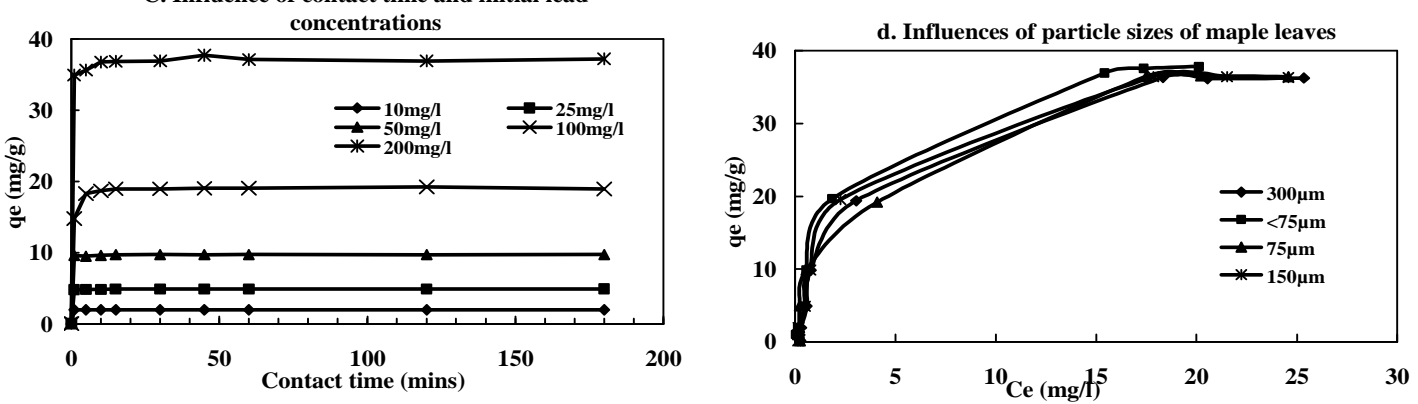

Figure 1 Effects of experimental conditions on $\mathrm{Pb}(\mathrm{II})$ removal from water by maple leaves. 

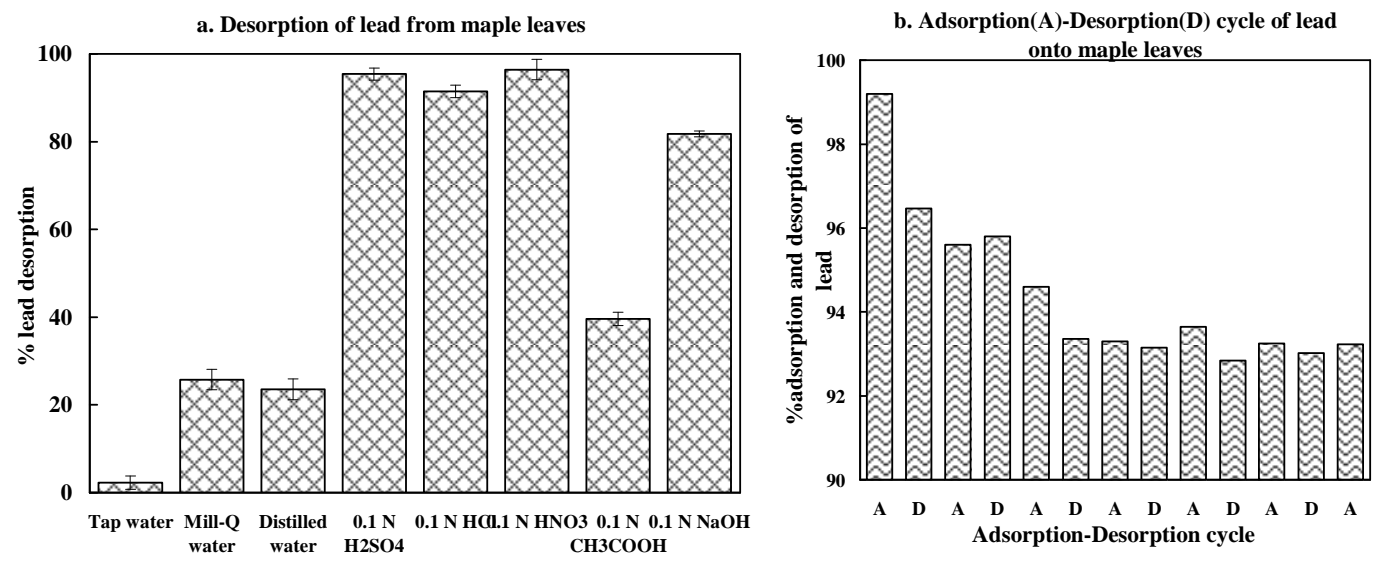

Figure 2 Regeneration of maple leaves from $\mathrm{Pb}(\mathrm{II})$ adsorption and Adsorption-Desorption cycle 

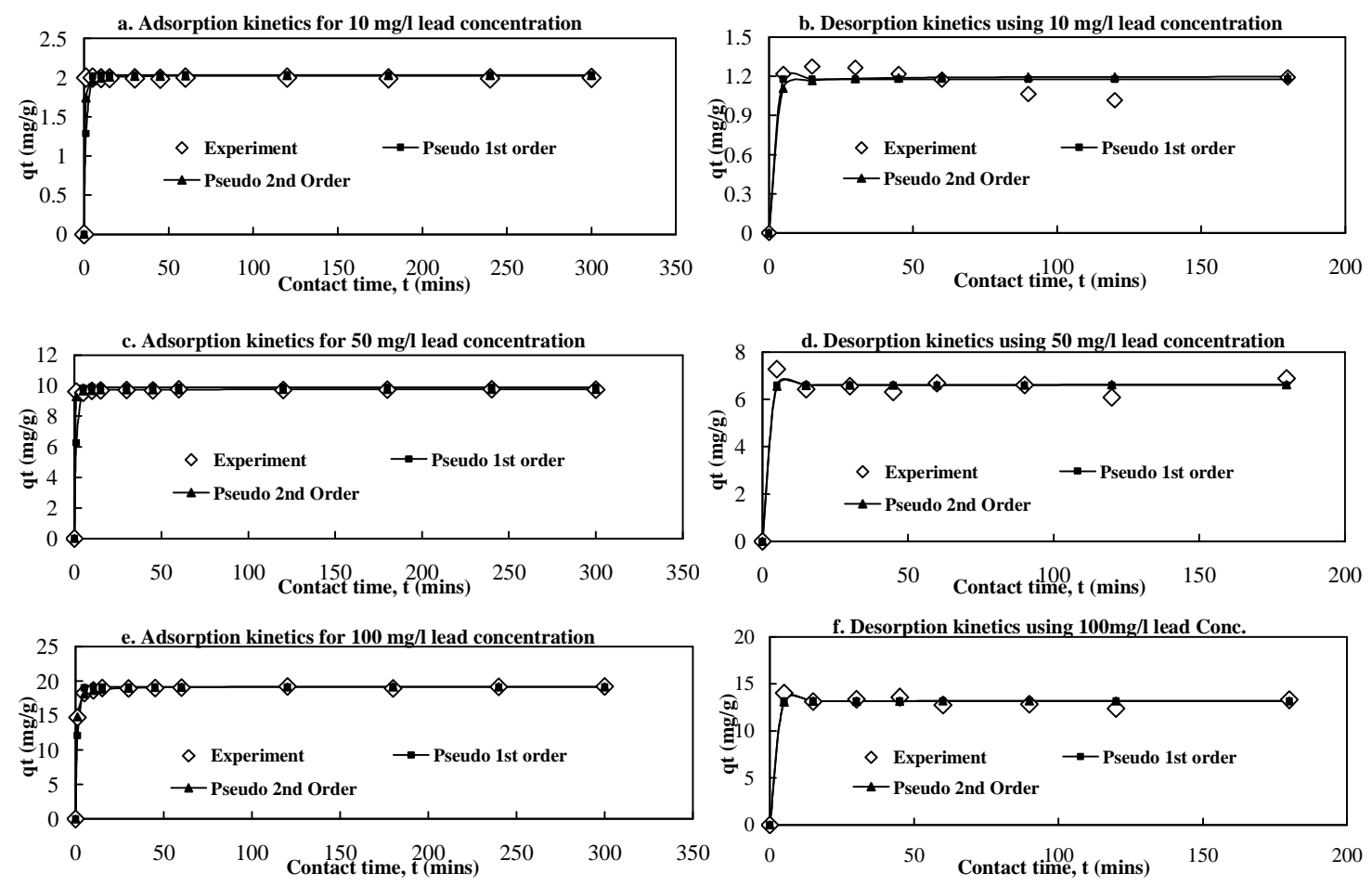

Figure 3 Kinetics modelling of adsorption and desorption of $\mathrm{Pb}(\mathrm{II})$ onto maple leaves with different doses (Co: 10, 50, $\left.100 \mathrm{mg} / \mathrm{l} ; \mathrm{d}: 0.5 \mathrm{~g} ; \mathrm{t}: 3 \mathrm{~h}: p H: 6-6.5 ; \mathrm{rpm}: 120 ; \mathrm{T}: 20^{\circ} \mathrm{C}\right)$ 

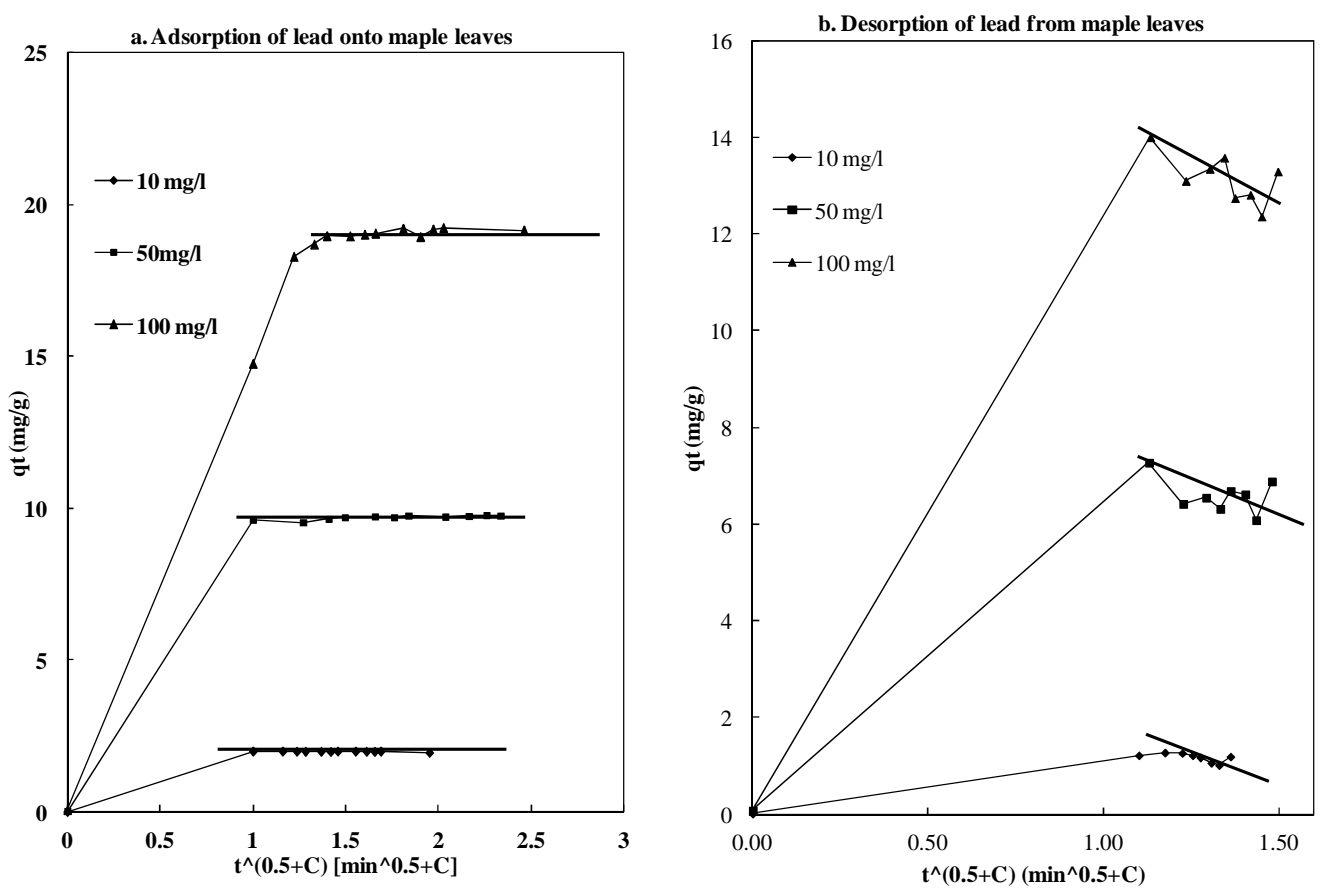

Figure 4 Plots of intra-particle diffusion kinetic model of maple leaves for adsorption and desorption (Co: 10, 50, $100 \mathrm{mg} / \mathrm{l}$; d: $0.5 \mathrm{~g}$; t: 24h: $p H: 6-6.5 ; \mathrm{rpm}: 120 ; \mathrm{T}: 20^{\circ} \mathrm{C}$ ) 

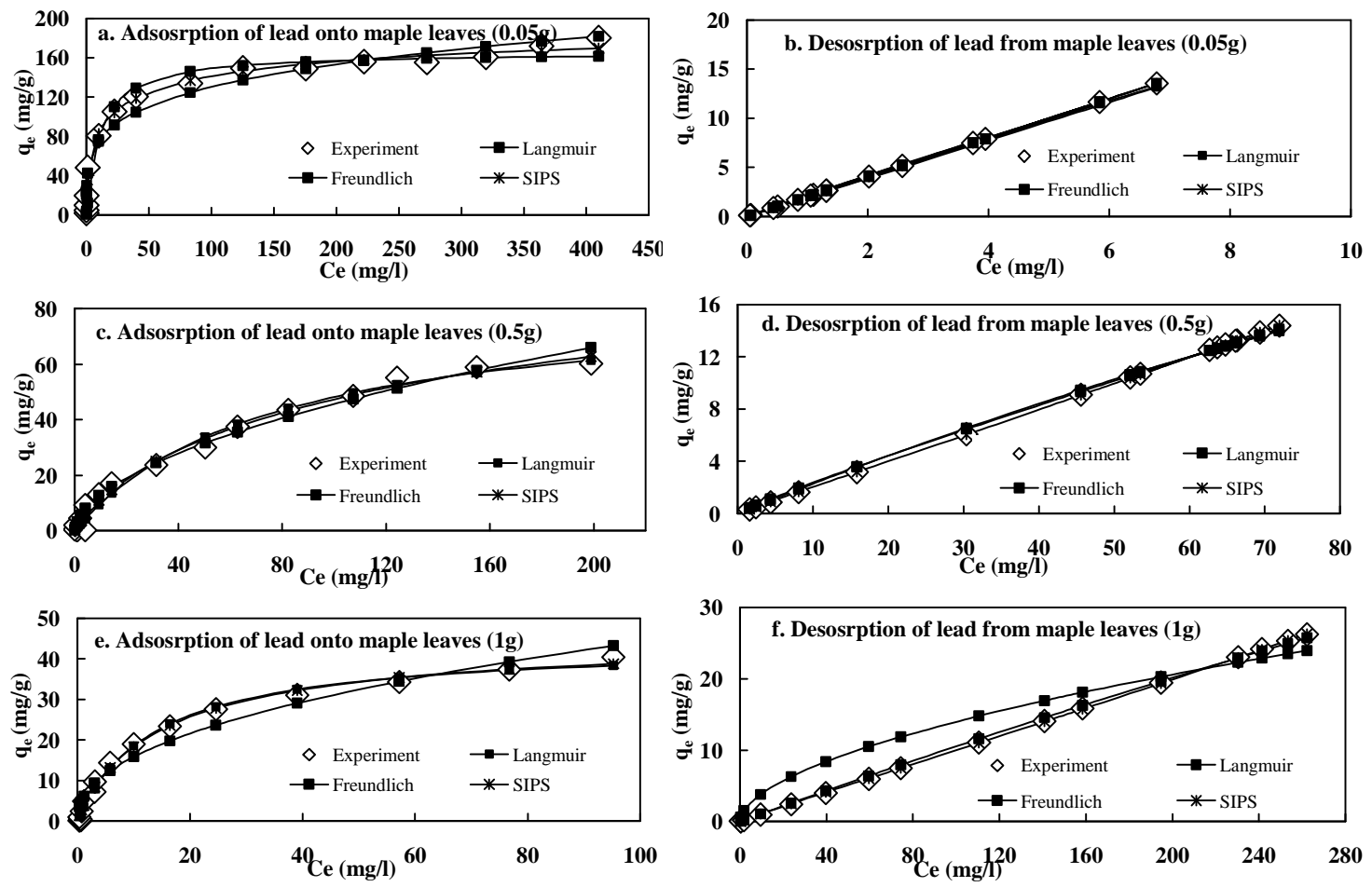

Figure 5 Isotherm modelling of adsorption and desorption of $\mathrm{Pb}$ (II) onto maple leaves with different doses (Co: 1-500 mg/l; d: 0.05-1 g; t: 3 h: pH: 6-6.5; rpm: 120; T: $\left.20^{\circ} \mathrm{C}\right)$ 


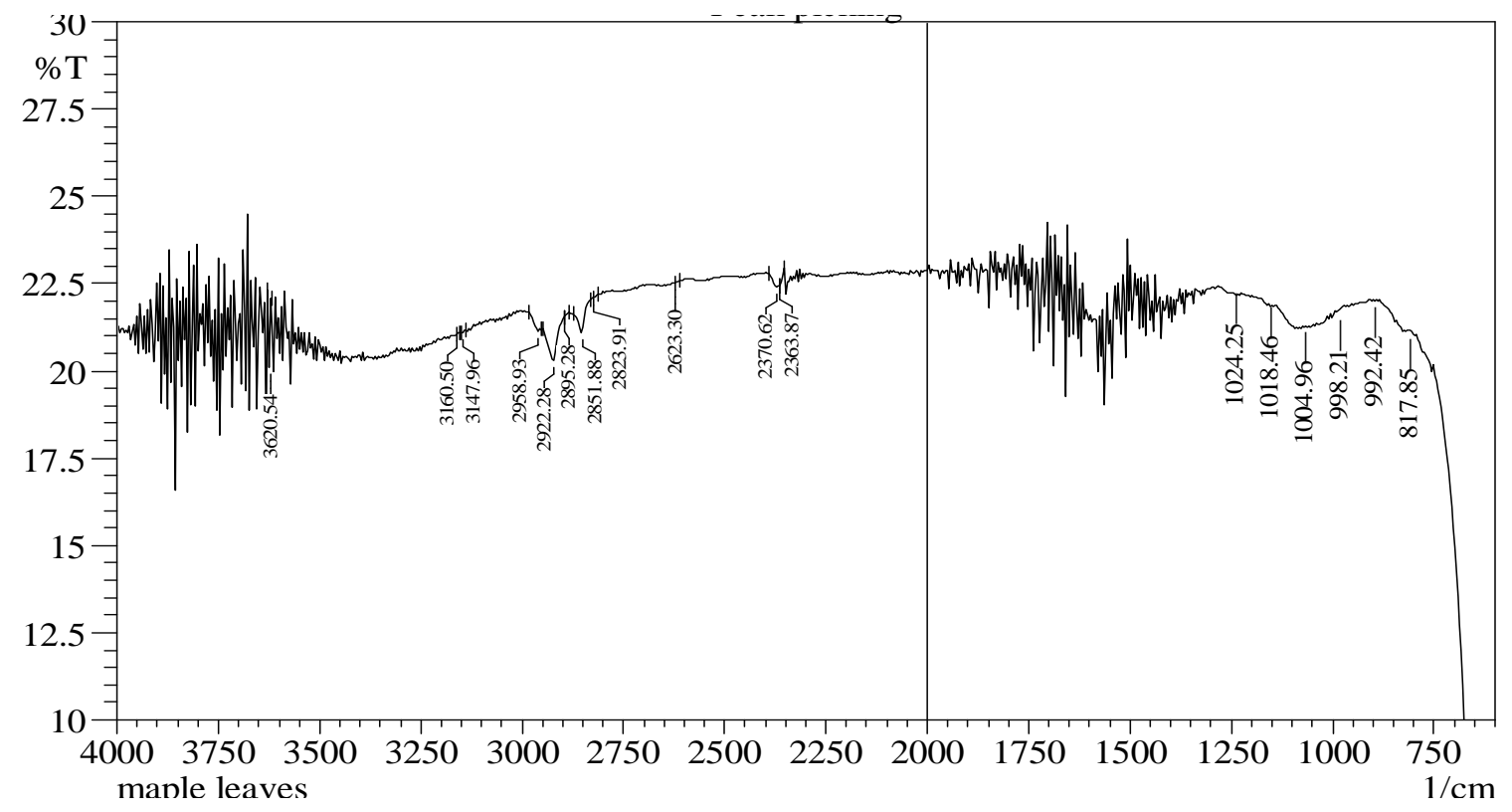

Figure 6 The FTIR spectra of maple leaves 

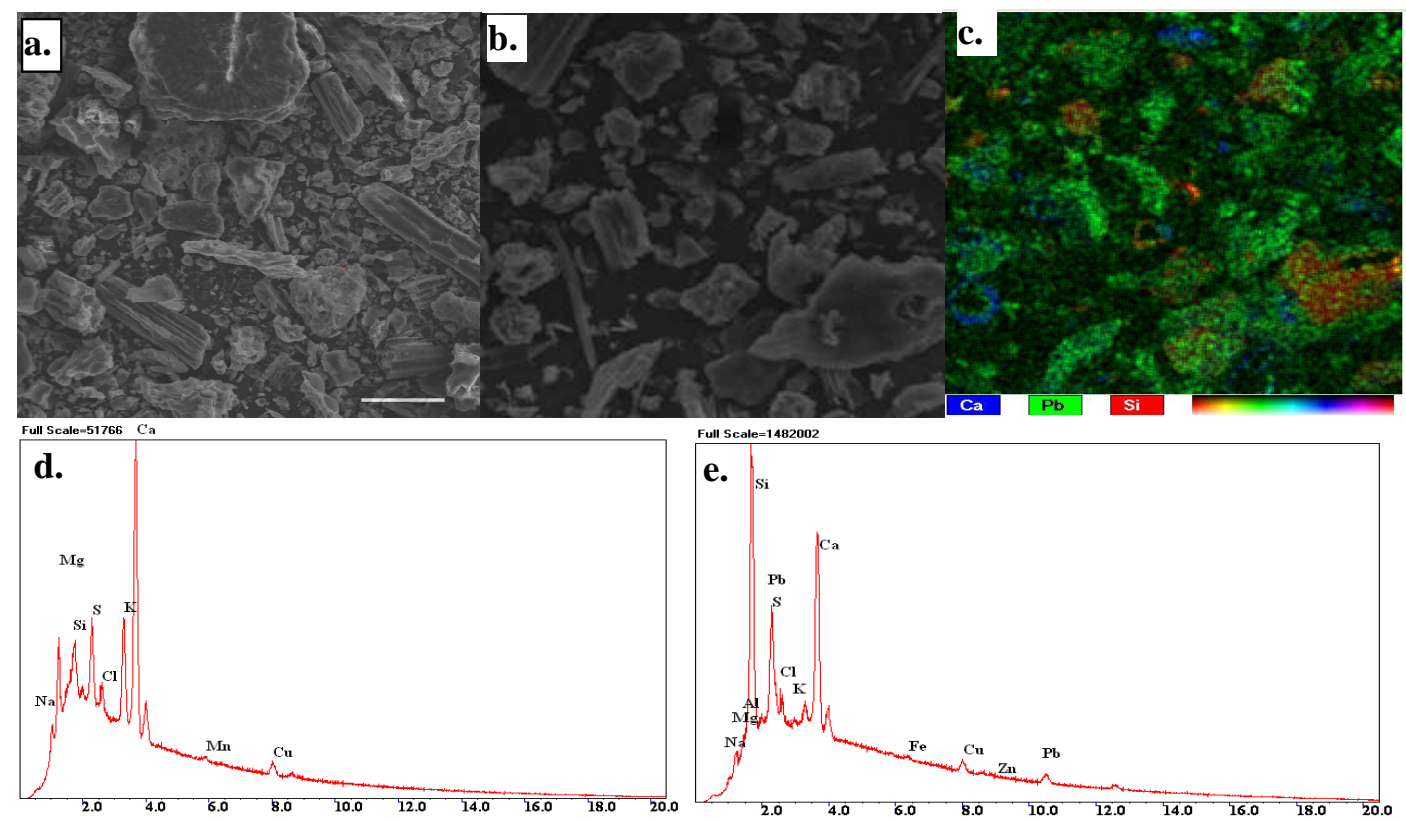

Figure 7 SEM micrograph $150 \times(\mathrm{HWOF}=600 \mu \mathrm{m})$ of (a) Maple leaves (b) Maple leaves exhausted with $\mathrm{Pb}$ (II) (c) X-ray mapping of maple leaves exhausted with $\mathrm{Pb}$ (II) (d) Spectra of maple leaves (e) Spectra of maple leaves exhausted with $\mathrm{Pb}(\mathrm{II})$ 